\title{
IMIDŽ LEASING USLUGA KAO FAKTOR POVEĆANJA INVESTICIONE AKTIVNOSTI U TRANZICIJSKIM ZEMLJAMA
}

\section{Image of Leasing Services as a Factor of Increased Investment Activity in Transition Countries}

\author{
Slobodan Vujić ${ }^{1}$, Saša Vujić ${ }^{2}$, Ajanović Mesud ${ }^{3}$
}

\begin{abstract}
Many investors for various reasons are not able to get and use bank loans and they face a complex problem how to actualize their desired investment, in its entirety, or how to finalize it, because they lack investment funds. In this situation a leasing arrangement is available for them, which will quickly and efficiently solve the problem. The leasing service is based on: quick decision about the request, simple procedures of forms, simple loan repayment guarantees, agreement about repayment deadline, high likelihood to get approved financing, quality of services and business efficiency.

The objective of this work is to show that in the procurement of equipment in forestry, like in other industries, it is strategically more advantageous to use a leasing arrangement rather than a bank loan. The leasing service enables the financing of equipment in forestry and thus it enables the increase of investment activities in forestry as well as in other industries in $\mathrm{BiH}$.

Primary surveys of users of leasing services will be used to prove this theory. Scientific analysis will be used to determine satisfaction so far in doing business with banks and satisfaction so far in doing business with leasing companies. Based on this work, individual leasing companies can apply this scientifically collected information to increase the volume of sale of their services, and thus to improve their results and business objectives.
\end{abstract}

Key words: Leasing service, forestry, financing, equipment, investment activity.

\footnotetext{
${ }^{1}$ VB Leasing BH , Fra Anđela Zvizdovića, 71000 Sarajevo, slobodan.vujic@,vbleasing.ba

${ }^{2}$ Ekonomski fakultet u Sarajevu,Trg oslobođenja-Alija Izetbegović 1, 71000 Sarajevo, sasa.vujic@efsa.unsa.ba

${ }^{3}$ VB Leasing BH, VB Leasing BH, Fra Anđela Zvizdovića, 71000 Sarajevo, mesud.ajanovic@vbleasing.ba
} 


\section{Izvod}

Mnogi investitori iz raznih razloga nisu u mogućnosti dobiti i koristiti bankarske kredite pa se nalaze pred složenim problemom, kako realizirati željenu investiciju bilo u cijelosti ili završiti, zbog nedostatka investicijskih sredstva. U takvoj situaciji stoji im na raspolaganju leasing aranžman, koji će brzo i efikasno riješiti problem. Leasing usluga temelji se na: brzom rješenju zahtjeva, jednostavnosti procedura obrazaca, jednostavnim garancijama otplate kredita, dogovaranju o roku otplate, visokoj vjerovatnoći za dobijanje odobrenja finansiranja te kvalitetu usluga i poslovnosti.

Cilj ovog rada je da ukaže da pri nabavci opreme u šumarstvu, kao i u drugim djelatnostima, strateški je povoljnije koristiti leasing aranžman nego bankarski kredit. Leasing usluga omogućava nabavku opreme u šumarstvu i na taj način povećava investicione aktivnosti kako u šumarstvu tako i u drugim djelatnostima u BiH.

Za dokazivanje postavljene teorije koristit će se primarna istraživanja kod korisnika leasing usluga. Naučnom analizom utvrdiće se dosadašnje zadovoljstvo klijenata u poslovanju sa bankama i leasing kompanijama. Na temelju ovoga rada pojedine leasing kompanije mogu aplikativno primijeniti na naučnoj osnovi prikupljene podatke, na povećanju obima prodaje svojih usluga, a time i poboljšanja svojih rezultata i ciljeva poslovanja.

Ključne riječi: Leasing usluga, šumarstvo, finansiranje, oprema, investiciona aktivnost.

\section{Uvod - Introduction}

Razvoj leasing aranžmana temelji se na obostranom ekonomskom interesu, kako davaoca tako i korisnika leasinga. U suštini, korisnik leasinga lakše nabavlja željenu opremu koju nije u mogućnosti unaprijed platiti. On dobija opremu i njenu otplatu vrši $\mathrm{u}$ periodu korištenja te opreme. $\mathrm{S}$ obzirom da se najčešće radi o nabavci skuplje proizvodne opreme, korisnik leasinga planira da otplatu vrši iz prihoda koje ostvaruje njenim korištenjem. Ukoliko se radi o fizičkoj osobi, ona lakše osigurava dio novčanih sredstava za otplatu u dužem periodu nego da osigura sva novčana sredstva pri kupovini unaprijed.

Kada se kupuje oprema za šumarstvo putem leasing aranžmana, opremu kupuje leasing kompanija i plaća je u cijelosti prodavcu (trgovcu) opreme za šumarstvo. Opremu bira fizičko lice (građanin) i uzima je u najam od leasing kompanije uz mjesečno plaćanje kamate (anuiteta). Leasing je engleska riječ ${ }^{4}$ i znači iznajmljivanje, davanje u najam, izdavanje pod zakup.

4 a) Engleska riječ „,to lease“ znači iznajmiti, dati u najam,

b) Engleska riječ „leasing“ znači sklapanje ugovora o najmu,

c) Engleska riječ „lessee“ znači korisnik leasinga, 


\section{Materijal i metode rada-Materials and Methods}

U ovome radu su korištene kombinacije više naučnih i istraživačkih metoda. Metodom analize istražujemo sadržaj, strukturu i međusobne veze i odnose predmeta istraživanja kako bi saznali u kojoj mjeri i kakav je uticaj kvantitativnih i kvalitativnih determinanti kanala prodaje. Metoda komparacije služila je za upoređivanje pokazatelja intenziteta.

Teorijski rad na literaturi obuhvatio je analizu već objavljenih knjiga, članaka, studija i sl. iz oblasti leasing usluga. Prikupljanje sekundarnih podataka je podrazumijevalo prikupljanje, sistematizaciju i obradu podataka o leasing kompanijama u BiH.

Za dokazivanje postavljene teorije koristit će se primarna istraživanja kod korisnika leasing usluga. Kroz primarna istraživanja izvršena su anketiranja (ili ispitivanja) klijenata u vezi sa njihovim dosadašnjim zadovoljstvom u poslovanju sa bankama i leasing kompanijama. Dobijene podatke obradili smo u posebnim tabelama (VUJIć 2009).

\section{Rezultati rada - Results of work}

\subsection{Značaj leasing usluga - Importance of leasing services}

Leasing usluga predstavlja finansiranje korisnika leasing aranžmana pri kupovini opreme koju mogu činiti: razne mašine za proizvodnju, kamioni, automobili, autobusi, putnička auta, informatička oprema, mašine za građevinarstvo, poljoprivredu, šumarstvo itd. Postoje tri osnovne leasing usluge: operativni leasing, finansijski leasing i „prodaj i uzmi nazad u leasing“. U okviru ovog asortimana leasing usluga postoje razne varijacije svake od navedenih vrsta.

U poslovanju leasinga pojavljuju se tri učesnika:

- proizvođač ili trgovac opremom,

- leasing kompanija koja kupuje opremu od proizvođača ili trgovca opremom i

- korisnik leasinga, koji uzima opremu u najam ili zakup.

Značaj leasing poslova može se promatrati sa aspekta davaoca usluge, tj. leasing kompanije i sa aspekta korisnika leasinga, tj. građanina koji kupuje opremu.

Sa aspekta davaoca usluge leasinga značaj tog poslovanja izražava se kroz ostvarivanje dobiti iz svog poslovanja. Leasing kompanija angažira svoja sredstva i kupuje opremu koju daje u najam građaninu i kroz mjesečnu kamatnu stopu i naplatu kamata ostvaruje prihod koji bi trebao biti veći od troškova poslovanja te na taj način ostvaruje dobit. Pri ovome treba imati u vidu da predmet zakupa zakupoprimcu isporučuje direktno proizvođač, odnosno isporučilac datog predmeta zakupa (BACKOVIĆ, 1997).

d) Engleska riječ „lessor“ predstavlja davaoca leasing usluga. 
Za korisnika leasing aranžmana (građanina) značajno je što na ovaj način nabavku opreme, npr. za šumarstvo, može brže i jednostavnije realizirati kroz lakše i brže obezbjeđenje finansijskih sredstava.

Zašto kompanije odnosno kupci, bilo da su pravna ili fizička lica koriste leasing ili kredit? I jedna i druga varijanta imaju za cilj dobijanje i korištenje potrebnog sredstva za rad ali na različit način finansiranja te nabavke.

S obzirom na to da su, na prvi pogled, kamatne stope koje zaračunava banka na kredit niže od kamatne stope koje zaračunava leasing kompanija, izgleda da je bolje i ekonomičnije finansirati nabavke iz bankarskih kredita. Međutim, praksa i dublja analiza potvrđuju da je ipak povoljnije koristiti leasing aranžman nego bankarski kredit.

\subsection{Razlika između leasing usluga i bankarskih usluga - Difference between leasing services and bank services}

Između leasing kompanije i banke postoje značajne razlike iako $\mathrm{u}$ jednom segmentu svog poslovanja imaju sličan ili isti motiv. Sličnost se manifestira samo u načelnoj pomoći fizičkoj osobi da riješi problem finansiranja nabavke željenog automobila /opreme.

Banke taj problem potencijalnog korisnika rješavaju kroz odobravanje finansijskog kredita pomoću kojeg korisnik kupuje željenu opremu. Leasing kompanije problem korisnika pri nabavci opreme za šumarstvo rješavaju na drugačiji način. One kupuju opremu koju želi i sam bira korisnik, s tim da mu je iznajmljuju. Korisnik duguje leasing kompaniji povrat angažiranih finansijskih sredstava u dogovorenom roku uvećane za kamatu. U ovom slučaju leasing kompanija je vlasnik kupljene opreme za šumarstvo, a korisnik ju je samo iznajmio na korištenje. Otplata angažiranih finansijskih sredstava vrši se kroz plaćanje najamnine.

U prvom slučaju, ako se koristi bankarski kredit, danom kupnje korisnik postaje vlasnik opreme za šumarstvo, a banci otplaćuje kredit uvećan za kamatu.

Leasing kompanije obično kao garanciju plaćanja anuiteta (najma opreme za šumarstvo) koriste konkretno opremu i u slučaju neplaćanja anuiteta (najma) oduzimaju opremu od korisnika i vraćaju je u svoj posjed. Na taj način leasing kompanije imaju jednostavniju proceduru odobravanja leasing aranžmana. Nasuprot tome, banke traže dodatna osiguranja povrata kredita i procedure su dosta formalne i spore. Iz tih razloga, kao i nekih drugih, kupci opreme za šumarstvo često se opredjeljuju za korištenje usluga leasing kompanija.

\subsection{Prednosti kupovine opreme za šumarstvo putem leasinga - Advantage of purchasing equipment for forestry through leasing}

Odgovor na pitanje da li koristiti kredit ili leasing zavisi od niza elemenata i okolnosti u kojima se nalazi potencijalni korisnik odnosno kupac opreme za šumarstvo. 
U principu, najpovoljnije je kupovinu vršiti iz vlastitih novčanih sredstava i bez korištenja kredita ili leasinga. Međutim, često potencijalni korisnici - građani nemaju dovoljno ili nikakvih novčanih sredstava i moraju koristiti bankarski kredit ili leasing usluge. U nekim slučajevima korisnici imaju novčana sredstva, ali se opredjeljuju da ih koriste u neke druge namjene i žele koristiti bankarski kredit ili leasing.

Pri odlučivanju da li koristiti bankarski kredit ili leasing aranžman, u razmatranje se uzimaju slijedeći elementi, koji obično idu u prilog leasing aranžmana:

-Brzina rješavanja zahtjeva. U poslovanju sa bankama pravna i fizička lica iskazala su najveći obim nezadovoljstva u brzini rješavanja zahtjeva. Nasuprot tome, i pravna i fizička lica u poslovanju sa leasing kompanijama iskazuju visoki nivo zadovoljstva $\mathrm{u}$ brzini rješavanja zahtjeva.

- Jednostavnost postupaka i obrazaca. I u grupi ovih elemenata odgovori anketiranih su vrlo slični prethodnim odgovorima. Oba segmenta korisnika (pravna i fizička lica) vrlo su nezadovoljni u pogledu jednostavnosti postupaka i obrazaca, dok za poslovanje sa leasing kompanijama ističu visok nivo zadovoljstva.

-Pomoć pri podnošenju zahtjeva. Dosadašnje zadovoljstvo u poslovanju sa bankama ili leasing kompanijama sa aspekta pomoći pri podnošenju zahtjeva ide u korist leasing kompanije. Pravna lica, a i fizička lica, nisu zadovoljna obimom pomoći pri podnošenju zahtjeva kod banaka. Isti korisnici usluga sasvim su zadovoljni sa pomoći koju dobijaju od leasing kompanija pri podnošenju zahtjeva.

-Vrste koleterala. I sa aspekta koleterala leasing kompanije su u prednosti u odnosu na banke. I u tom segmentu poslovanja i pravna i fizička lica su znatno zadovoljnija u poslovanju sa leasing kompanijama nego sa bankama.

-Dodatne usluge. U ovoj oblasti leasing kompanije su znatno aktivnije od banaka te je zadovoljstvo pravnih i fizičkih osoba znatno veće $u$ poslovanju sa leasing kompanijama nego u poslovanju sa bankama.

Ocjenjujući ukupnu komparaciju zadovoljstva u poslovanju sa bankama u odnosu na poslovanje sa leasing kompanijama, a na temelju primarnog istraživanja i navedenih tabela i podataka može se konstatirati da su pravna i fizička lica mnogo zadovoljnija u poslovanju sa leasing kompanijama nego u poslovanju sa bankama.

Pored primarnog istraživanja vezanog za zadovoljstvo u poslovanju sa bankom ili sa leasing kompanijom, posebno su istražene i komparirane prednosti i nedostaci finansiranja nabavke opreme putem leasinga i bankarskog kredita. Podaci su prikupljeni od 172 pravna lica i 274 fizička lica ili ukupno 446 lica što je dovoljan uzorak za kvalitetno analiziranje i donošenje relevantnih zaključaka.

Svakom anketiranom licu omogućeno je da se od navedenih jedanaest prednosti opredjeli za onu koja je najprihvatljivija. Svaku prednost za jednog ili drugog davaoca usluge moguće je gradirati u tri stupnja: minimalna prednost, značajna prednost $\mathrm{i}$ vrlo visoka prednost. Svi dobijeni podaci su kodirani i tabelirani (VUJIĆ, 2009) kako bi se 
lakše izvršila analiza i utvrdile činjenice te pokazalo na čijoj su strani prednosti u finansiranju nabavke opreme.

U narednom tekstu daje se kraći osvrt na svih 11 vrsta prednosti za koje su se anketirani izjašnjavali:

\begin{tabular}{|l|l|l|}
\hline 1. Jednostavniji načina osiguranja \\
novčanih sredstava za nabavku \\
$\begin{array}{l}\text { opreme Anketirani su dominantno } \\
\text { dali prednost leasingu }(71,7 \%) \text { u }\end{array}$ \\
odnosu na bankarske kredite \\
$(28,3 \%)$ uz opredjeljenje da je \\
značajna ili vrlo visoka prednost \\
leasinga.
\end{tabular}

Grafikon 1. Jednostavnost osiguranja novčanih sredstava

Graf 1. Simple insurance of funds

\begin{tabular}{|l|l|l|}
\hline 2. Visina kamata U ovom slučaju \\
anketirani su istakli prednost \\
bankarskog kredita $(58,3 \%)$ u \\
odnosu na leasing $(41,7 \%)$ uz \\
naglašavanje da je to značajna \\
prednost bankarskih kredita.
\end{tabular}

Grafikon .2. Visina kamata

Graf 2. Interest rate

3. Pojednostavljeni način garancije otplate U ovom elementu anketirani daju visoku prednost leasingu $(69,7 \%)$ u odnosu na bankarski kredit (30,3\%), pri čemu naglašavaju vrlo visoku prednost leasinga.

Grafikon 3. Pojednostavljeni način garancija otplate

Graf 3. Simplified repayment guarantee 


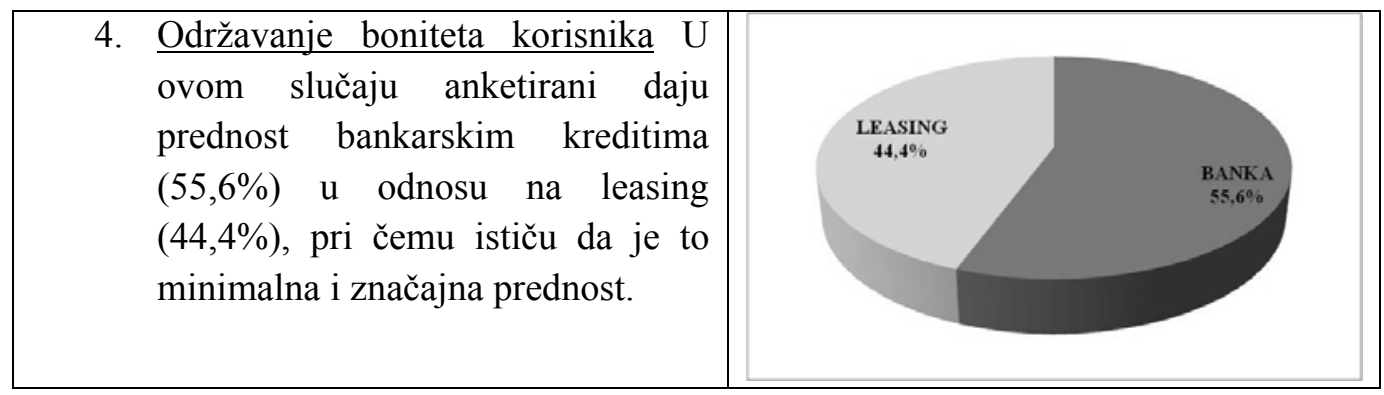

Grafikon 4. Održavanje boniteta korisnika

Graf 4. Maintaining credit standing of users

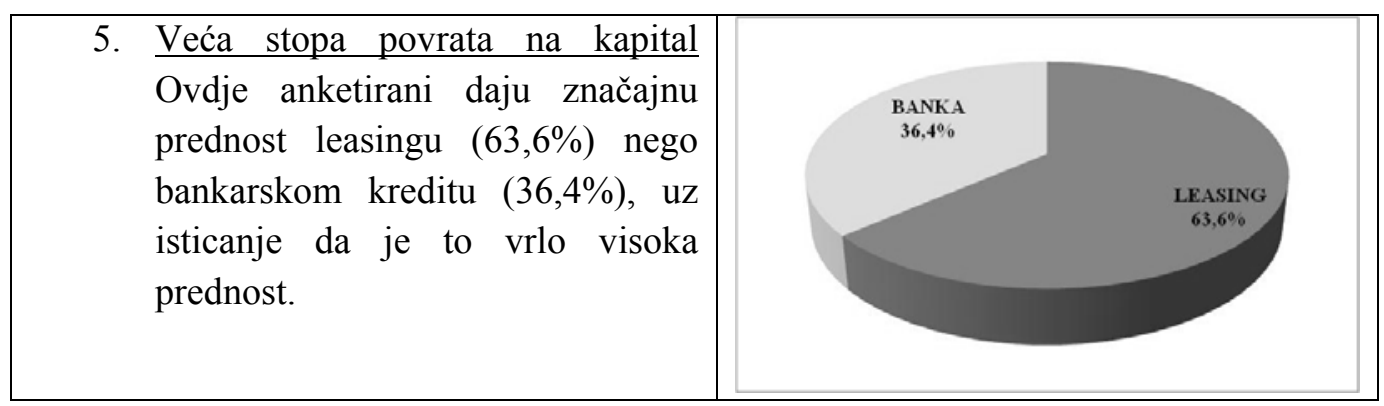

Grafikon 5. Veća stopa povrata na kapital

Graf 5. Higher rate of return on capital

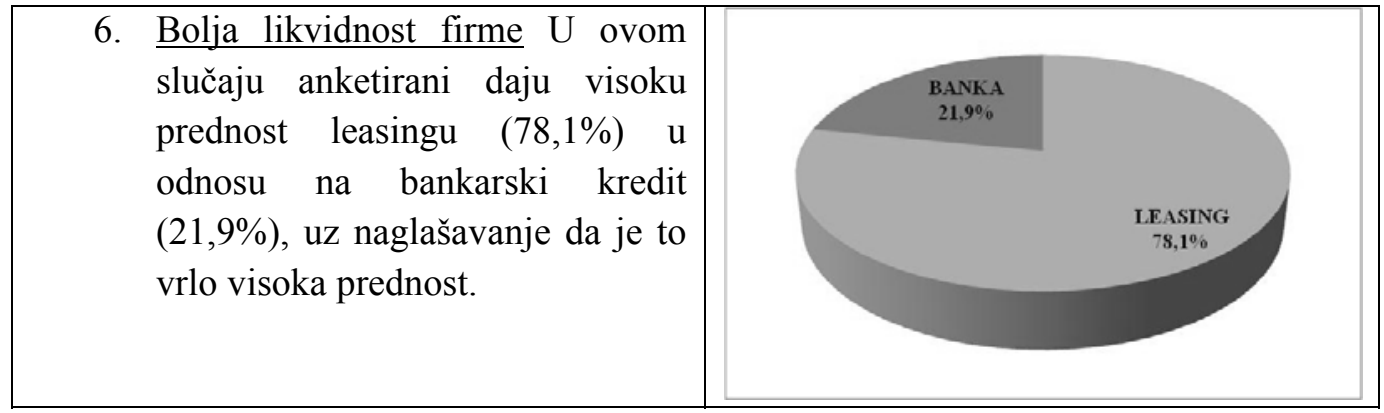

Grafikon 6. Bolja likvidnost firme

Graf 6. Better liquidity of company 


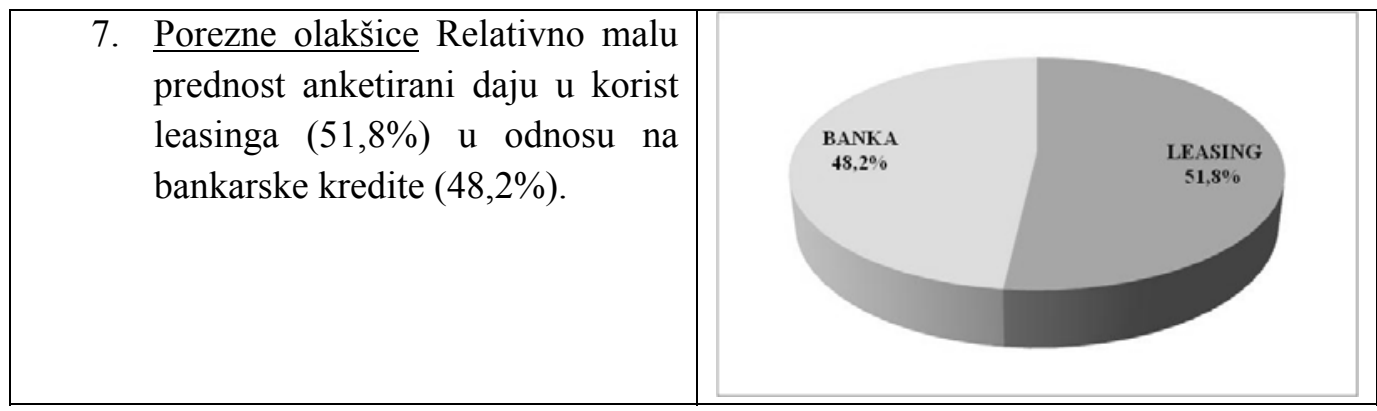

Grafikon 7. Porezne olakšice

Graf 7. Tax relief

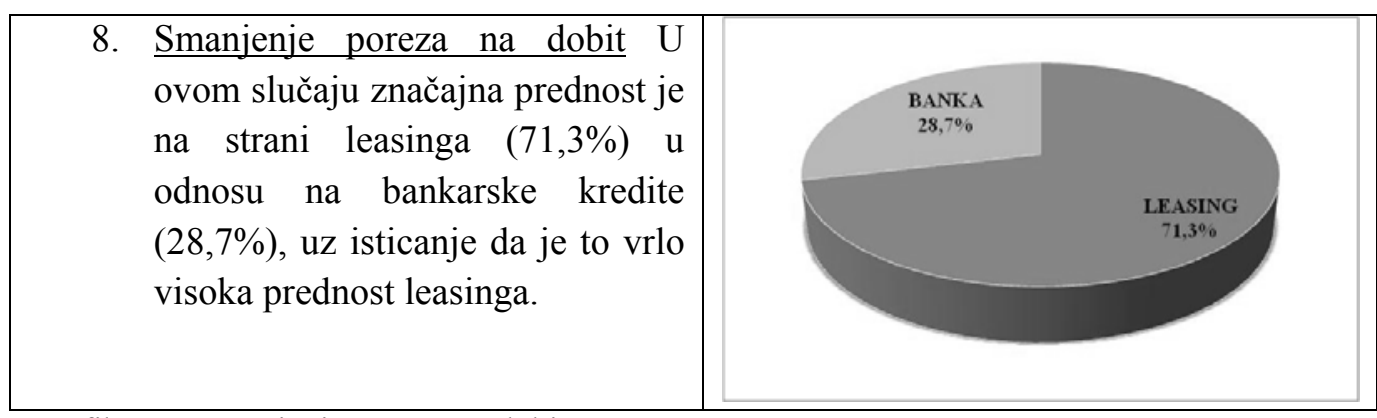

Grafikon 8. Smanjenje poreza na dobit

Graf 8. Profit tax reduction

9. Troškovi obračuna amortizacije U ovom primjeru anketirani daju neznatnu prednost leasingu $(52,7 \%)$ u odnosu na bankarske kredite (47,3\%).

Grafikon 9. Troškovi obračuna amortizacije

Graf 9. Depreciation costs 


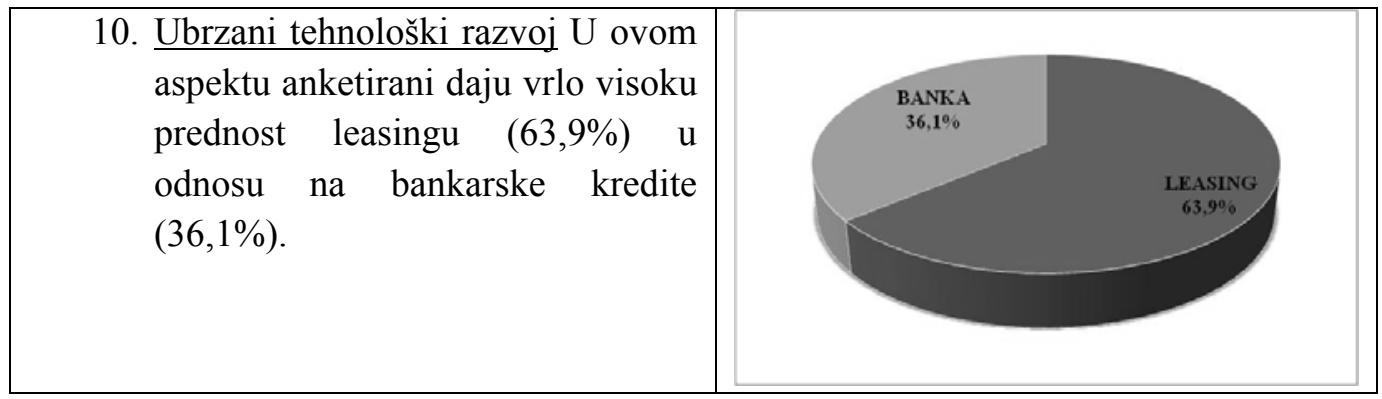

Grafikon 10. Ubrzan tehnološki razvoj

Graf 10. Accelerated technological development

\section{Povećanje kreditnog zaduženja (kod finansiranja putem operativnog leasinga). U ovom elementu vrlo visoka prednost (nedostatak) se daje bankarskom kreditu $(71,7 \%)$ u odnosu na leasing $(28,3 \%)$, a što se tumači kao prednost leasinga.}

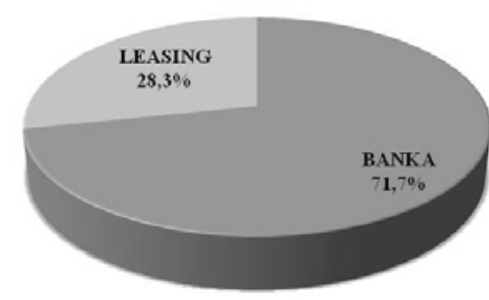

Grafikon 11. Povećanje kreditnog zaduženja

Graf 11. Increased loan debt

Dajući generalnu ocjenu za svih jedanaest vrsta prednosti može se vidjeti da su one u samo dva slučaja na strani bankarskog kredita - visini kamate i održavanju boniteta korisnika. U svih ostalih devet mogućih prednosti one su na strani leasinga. U davanju sumarne ocjene zadovoljstva pri rješavanju finansiranja nabavke opreme, pravna i fizička lica su se mogla izjasniti u korist leasing kompanije ili u korist banke. (VUJIĆ, 2009).

\section{Zaključak - Conclusion}

Iz prethodnog izlaganja vrlo su uočljive pogodnosti i prednosti pri kupovine opreme za šumarstvo putem leasing aranžmana a ne putem bankarskog kredita. U suštini, brže, jednostavnije i efikasnije se može realizirati nabavka opreme za šumarstvo putem leasing aranžmana nego putem traženja i dobijanja bankarskog kredita.

Pored osnovne funkcije investiranja u šumarstvu koja je obezbjeđenje biološke reprodukcije šumskih resursa, ono takođe obezbjeđuje i povećanje proizvodnih kapaciteta šuma,i dr. 
Investiranjem u šumarstvo neće se postići samo direktni finansijski efekti izraženi u novcu, nego i niz indirektinih efekata kao što su sociološke, ekološke opšte koristi.

Samim tim, u trenucima opšte nelikvidnosti u svjetskoj privredi, kao i privredi Bosne i Hercegovine, teret investicija će najvećim dijelom snositi preduzeća sumarstva.

S obzirom na obime potrebnih investicija, leasing kao način investiranja i mogućnost nabavke tehnološki najnovijih sredstava za rad, predstavlja svakako jednu od najboljih mogućnosti za podizanje produktivnosti i kvaliteta rada preduzeća u šumarstvu.

U radu je dokazana i potvrđena postavljena hipoteza da je pri nabavci opreme strateški povoljnije koristiti leasing aranžman nego bankarski kredit.

Prednosti leasing aranžmana nad bankarskim kreditom je u slijedećem:

- jednostavniji način osiguranja novčanih sredstava za nabavku opreme,

- brzo odobravanje,

- lakše osiguranje garancija otplate,

- održavanje boljeg boniteta korisnika,

- povećanje stope povrata na kapital,

- bolja likvidnost firme,

- povoljnije poreske olakšice,

- povoljniji obračun amortizacije i

- zaštita od povećanja kamatne stope.

Prednosti bankarskog kredita nad leasing aranžmanom svodi se samo na jednu prednost - niža kamatna stopa.

Ukoliko se uporede prednosti i nedostaci jednog ili drugog metoda osiguranja sredstava za finansiranje nabavke opreme, uočljiva je strateška prednost leasing aranžmana nad bankarskim kreditom.

U operativnom leasingu ne dolazi do prenosa vlasništva nad predmetom leasinga. Korisnik leasinga sam bira predmet leasinga i za korištenje tog predmeta plaća leasing kompaniji ugovorenu naknadu. Po isteku ugovorenog roka leasinga, korisnik navedeni predmet (automobil, mašina, oprema i sl.) vraća davaocu leasinga, kojeg on može prodati ili dati u novi leasing u skladu sa preostalom upotrebnom vrijednosti sredstva. U periodu trajanja operativnog leasinga sredstvo je vlasništvo leasing kompanije i ona je dužna obračunavati amortizaciju na svoj teret. Troškove korištenja i održavanja sredstva snosi korisnik leasinga. Plaćanje rata za leasing korisnik tretira kao trošak, a isti iznos davalac tretira kao prihod. Posebna varijacija operativnog leasinga je leasing sa dogovorenim ostatkom vrijednosti na kraju leasing perioda.

Finansijski leasing se temelji na motivu „koristi i zadrži“. Ovaj oblik leasinga u startu kroz ugovor predviđa preuzimanje vlasništva nad predmetom leasinga ali po isteku ugovorenog roka. Korisnik leasinga plaća mjesečnu naknadu, a sredstvo evidentira u svom bilansu imovine i na njega obračunava amortizaciju. Davalac 
leasinga zadržava pravo vlasništva nad sredstvom sve do posljednje rate i to služi kao osnovna garancija plaćanja svih rata. Davalac leasinga ne obračunava amortizaciju sredstva. Mjesečna rata leasinga kod davaoca se evidentira kao prihod, a kod korisnika leasinga kao trošak poslovanja.

Da bi firme poboljšale svoju likvidnost i došle do gotovine, često leasing kompaniji prodaju svoje stalno sredstvo, a potom to isto sredstvo uzimaju na korištenje putem leasing aranžmana. Na ovaj način firma dobija potreban novac, a i dalje koristi isto sredstvo (mašinu, auto, opremu i sl.), s tim da sada plaća u mjesečnim ratama leasing kompaniji iznajmljivanje tog sredstva. U ovom slučaju vlasništvo nad sredstvom prelazi sa firme prodavca na leasing kompaniju a pravo na korištenje sredstva ostaje kod prodavca (ranijeg vlasnika sredstva).

\section{Literatura - References}

BACKović, E. (1997) „Poslovne finansije“, redaktor Zijad Njuhović, Svjetlost, FEINEN, K. (2006) "Das Leasinggeschäft"

KOTLER, PH. (2001) «Upravljanje marketingom»; Mate, Zagreb,

LINDA, D., D.MAURICIO, O. LoUIS, W. OLIVEr, (2003) “ Leasing for small and micro enterprises", International labor organization

VuJı́, S. (2009), Doktorska disertacija: „Nivo uticaja kvantativnih i kvalitativnih determinanti kanala prodaje na modeliranje efikasne korporativne marketing strategije Leasing kompanije“, Ekonomski fakultet Sarajevo,

\section{Summery - Sažetak}

From the previous presentation it is very clear that there are benefits and advantages in purchasing forestry equipment through leasing arrangements instead of bank loans.

With investment in forestry, in addition to direct financial effects expressed in money, a series of indirect effects can also be achieved, such as sociological and ecological general benefits.

This paper proves and confirms the hypothesis, which is put forward in the introduction, that for the purchase of equipment it is strategically more advantageous to use leasing arrangements rather than bank loans.

Advantages of leasing arrangements over bank loans consist in the following:

- simpler method of securing money for the purchase of equipment,

- quick approval,

- easier securing of repayment guarantees,

- better credit standing of users, 
- increased rate of return on capital,

- better liquidity of company,

- more suitable tax relief,

- more suitable depreciation calculation, and

- protection from increased interest rate.

Advantage of bank loans over leasing arrangements comes down only to one advantage:

- lower interest rate.

If we compare advantages and disadvantages of one method over the other method of securing money for financing the purchase of equipment, it is noticeable that leasing arrangements have a strategic advantage over bank loans 


\title{
PRIHODI I TROŠKOVI PROIZVODNJE U ŠUMARSTVU FEDERACIJE BOSNE I HERCEGOVINE*
}

\section{Revenues and costs of forestry production in Federation of Bosnia \& Herzegovina}

\author{
Sabina Delić ${ }^{1}$, Mersudin Avdibegović ${ }^{1}$
}

\begin{abstract}
This paper deals with the revenues analyses realized in B-H Forest Management Companies (FMCs) as well as the structure of related production costs. As the revenues of FMCs come mainly from wood assortments production, the achieved prices and quality structure of felling are prevailing factors in total revenue generation.

The main goal of this analysis is to point out on different revenues obtaining possibilities caused by various production conditions between individual FMCs. Besides, the costs structure varies among the FMCs due to different human resources circumstances and materially/technically conditions. Thus, the production costs of forest products extremely vary with direct consequences on Forest Management Companies' profitability and their reproductive ability. This follows to different investment capacity of FMCs, first of all in terms of biological reproduction investments. The results of previous research points out on high level on synchronization between the amount of investments in biological reproduction and financial capabilities of FMCs. However, it should correspond to the real needs in concrete situation. This should lead to violation of sustainability principle, as a major principle of forest resources management.
\end{abstract}

Key words: revenue, costs of production, profitability, biological reproduction investment, sustainable forest management

\section{Izvod}

U ovom radu je izvršena analiza prihoda koji se ostvaruju u šumarstvu Federacije BiH po šumarskim preduzećima, te analiza strukture troškova koji se javljaju u poslovanju preduzeća. S obzirom da se prihodi preduzeća uglavnom baziraju na realizovanim

\footnotetext{
${ }^{*}$ Rad je prezentiran na Međunarodnoj konferenciji "Forestry Science Between Economy and Society Demands" održanoj u Sarajevu, oktobra 2008. g

${ }^{1}$ Šumarski fakultet Univerziteta u Sarajevu - Faculty of Forestry University of Sarajevo
} 
drvnim sortimentima, odlučujuću ulogu u njihovom formiranju ima, pored cijena šumskih drvnih sortimenata i kvalitetna struktura etata.

Cilj ove analize jeste da se ukaže na različite mogućnosti sticanja prihoda kao posljedice različitih uslova privređivanja preduzeća.

Pored toga, struktura troškova je različita po pojedinim preduzećima zbog različite zastupljenosti materijalno-tehničkih i ljudskih resursa. Struktura cijene proizvodnje proizvoda šumarstva izrazito varira između preduzeća, što se neminovno odražava na njihovu rentabilnost, a takođe i na njihovu akumulativnu i reproduktivnu sposobnost. Iz toga proizilazi i ekonomska mogućnost realizacije potrebnih investicionih ulaganja, a prije svega bioloških investicija. Ranije analize pokazuje da se obim bioloških investicija usklađuje sa raspoloživim finansijskim mogućnostima preduzeća, a ne prema realnim potrebama u konkretnim situacijama (DELIĆ, 2008). To bi moglo dovesti do narušavanja principa održivosti, kao osnovnog principa gospodarenja šumskim resursima.

Ključne riječi: prihod, troškovi proizvodnje, profitabilnost, investicije u biološku reprodukciju, održivo gospodarenje

\section{UVOD - Introduction}

Šumarstvo predstavlja integralni dio cjelokupne nacionalne proizvodnje, čiji je osnovni zadatak zadovoljenje društvenih potreba za proizvodima od drveta i ostalim proizvodima i uslugama čija je proizvodnja vezana za šumu. To je djelatnost koja gospodari (koristi, obnavlja i upravlja) jednim od najvažnijih prirodnih resursa i koji predstavlja uslov za odvijanje životnih aktivnosti i opstanka čovjeka. Iz ovog proističe značajna uloga šumarstva u privredi jedne zemlje, gdje se ne smije zanemariti da šumarstvo vršeći privrednu aktivnost vrši istovremeno i mnogobrojne druge općekorisne funkcije (ŠAKOVIĆ, 1998).

$\mathrm{S}$ obzirom na multifunkcionalnost šumarstva, mogućnosti sticanja prihoda preduzeća koja gospodare šumskim resursima su velike. I pored toga, prihodi preduzeća šumarstva Federacije $\mathrm{BiH}$ se uglavnom baziraju na realizovanim drvnim sortimentima. Zato su kvalitet etata i cijene šumskih drvnih sortimenata najvažnije uticajne varijable na ukupan prihod preduzeća. Kvalitet etata zavisi od stanja šuma kojima gospodare pojedina preduzeća. Na ovaj faktor se u kratkom roku ne može značajno uticati, osim preko povećanja stepena iskorištenosti etata u što je moguće „vrednije“ sortimente. Cijene šumskih drvnih sortimenata bi trebale biti rezultat odnosa ponude i potražnje za ovim proizvodima u razvijenim tržišnim uslovima. Međutim, u analiziranoj godini realizacija proizvedenih šumskih drvnih sortimenata se uglavnom odvijala prema propisanim cjenovnicima od strane pojedinih preduzeća, uz značajna variranja cijena istih vrsta sortimenata između preduzeća.

Uspješnost poslovanja preduzeća zavisi ne samo od stečenog ukupnog prihoda, nego i od ostvarenih troškova u proizvodnji. Struktura troškova preduzeća 
šumarstva zavisi od prirodnih uslova privređivanja i različitog stepena iskorištenosti ljudskih i materijalno-tehničkih resursa.

Posljedica toga je različit rezultat poslovanja koji se direktno odražava na reproduktivnu sposobnost preduzeća.

\section{CILJEVI RADA I PODRUČJE ISTRAŽIVANJA - The aims of work and research area}

Cilj ove analize jeste da se ukaže na različite mogućnosti sticanja prihoda i ostvarenja troškova kao posljedice nejednakih prirodnih uslova privređivanja preduzeća i različitog stepena zastupljenosti materijalno-tehničkih i ljudskih resursa. Iz toga proizilazi poslovni rezultat i različite mogućnosti pojedinih preduzeća da izvršavaju svoje obaveze prema šumskom resursu, jer se ne nalaze u ravnopravnom položaju. U cilju dokazivanja ovog stava, u radu su urađene analize:

- ukupnog prihoda i njegove strukture, cijena pojedinih šumskih proizvoda i kvalitetne strukture etata,

- strukture troškova poslovanja, te

- analiza poslovnog rezultata.

Istraživanje se odnosi na poslovanje 8 kantonalnih šumskogospodarskih preduzeća (ŠGP) koja egzistiraju na području Federacije (Unsko-sanske šume, Šume TK, ŠGP Zeničko-dobojskog kantona, Bosansko-podrinjske šume, Srednjobosanske šume, ŠGD Ž ZH d.o.o. Posušje, Sarajevo šume, Hercegbosanske šume), te 4 preduzeća u Hercegovačko-neretvanskom kantonu koja su organizacijski samostalna (Šumarstvo Prenj, Šumarstvo Ljuta, Šumarstvo Srednjeneretvansko i HB šume). Za analizu su korišteni zvanični podaci iz Izvještaja o poslovanju preduzeća za 2006. godinu.

\section{REZULTATI ISTRAŽIVANJA - The results of the study}

\subsection{Ukupan prihod i njegova struktura}

Ukupan prihod u šumarstvu Federacije $\mathrm{BiH}$ u 2006. godini je iznosio 182,383 miliona KM, od čega je 79,8 \% ili 145,6 mil. KM ostvareno prodajom šumskih drvnih proizvoda, a preostalih $20,2 \%$ su prihodi ostvareni po drugim osnovama. Dio prihoda po drugim osnovama odnosi se na prihode od realizacije nedrvnih proizvoda, izvršenih usluga, a u nekim preduzećima značajan udio po osnovu korištenja sredstava iz federalnog i kantonalnih budžeta. Struktura prihoda u pojedinim preduzećima jako varira, što je predstavljeno u tabeli 1 . U nekim preduzećima je zastupljenost prihoda po osnovu prodaje drvnih sortimenata $50 \%$, dok je kod drugih taj procenat čak i $97 \%$.

Ovaj odnos i struktura prihoda ukazuje da šumarstvo svoj prihod uglavnom bazira na šumskim drvnim sortimentima. Naše šume su bogata nalazišta različitih nedrvnih proizvoda, ali, nažalost, preduzeća ne koriste ovu mogućnost kako bi povećala svoje prihode. S obzirom na to, cijene šumskih drvnih sortimenata, kao i 
kvalitetna struktura etata, imaju odlučujuću ulogu u formiranju ukupnog prihoda šumarstva.

Tabela 1. Struktura ostvarenog ukupnog prihoda u 2006. godini

Table 1. Structure of realised revenues, 2006.

\begin{tabular}{|c|c|c|c|c|c|}
\hline \multirow{3}{*}{$\begin{array}{l}\text { ŠUMSKOGOSPODARSKO } \\
\text { PREDUZEĆE }\end{array}$} & \multicolumn{5}{|c|}{ Struktura ukupnog prihoda } \\
\hline & \multicolumn{2}{|c|}{ Prihod od drveta } & \multicolumn{2}{|c|}{ Ostali prihodi } & \multirow{2}{*}{$\begin{array}{c}\begin{array}{c}\text { Ukupan } \\
\text { prihod }\end{array} \\
\text { KM }\end{array}$} \\
\hline & KM & $\%$ & KM & $\%$ & \\
\hline Unsko-sanske šume & 28.141 .582 & 78.04 & 7.916 .822 & 21.96 & 36.058 .404 \\
\hline Šume TK & 13.594 .376 & 83.01 & 2.781 .793 & 16.99 & 16.376 .169 \\
\hline ŠGP ZE-DO kantona & 28.095 .946 & 82.83 & 5.823 .753 & 17.17 & 33.919 .699 \\
\hline Bosansko-podrinjske šume & 1.062 .422 & 79.12 & 280.301 & 20.88 & 1.342 .723 \\
\hline Srednjobosanske šume & 26.819 .828 & 76.34 & 8.311 .875 & 23.66 & 35.131 .703 \\
\hline Šumarstvo "Prenj" Konjic & 4.043 .816 & 87.13 & 597.543 & 12.87 & 4.641 .359 \\
\hline Šmarstvo "Ljuta" & 537.508 & 50.31 & 530.798 & 49.69 & 1.068 .306 \\
\hline $\begin{array}{l}\text { Šumarstvo } \\
\text { "Srednjeneretvansko" }\end{array}$ & 635.043 & 68.61 & 290.509 & 31.39 & 925.552 \\
\hline HB šume & 522.718 & 50.59 & 510.528 & 49.41 & 1.033 .246 \\
\hline Z ZH d.o.o.Posušje & 382.206 & 67.65 & 182.804 & 32.35 & 565.010 \\
\hline Sarajevo-šume & 11.767 .388 & 57.68 & 8.633 .825 & 42.32 & 20.401 .213 \\
\hline Hercegbosanske šume & 29.997 .021 & 97.01 & 922.983 & 2.99 & 30.920 .004 \\
\hline FEDERACIJA BIH & 145.599 .854 & 79.83 & 36.783 .534 & 20.17 & 182.383 .388 \\
\hline
\end{tabular}

Izvor: Izvještaji o poslovanju preduzeća za period januar-decembar 2006. godine

\subsubsection{Analiza cijena šumskih drvnih proizvoda}

Prema raspoloživim informacijama šumski drvni proizvodi četinara i lišćara su uglavnom realizovani po cijenama koje su propisane cjenovnikom na nivou preduzeća. Samo u nekim preduzećima bila je zastupljena prodaja putem licitacije, ali se radi o prodaji malih količina drvnih sortimenata. Prosječne cijene pojedinih sortimenata četinara i lišćara u Federaciji $\mathrm{BiH}$ se mogu vidjeti iz grafikona 1 i 2 . Uočava se da cijene istih drvnih sortimenata variraju između pojedinih preduzeća. Metodika izrade minimalnih cjenovnika u preduzećima nije poznata, ali se može pretpostaviti da se radi o iskustvenim podacima. Tako je, npr., prosječna cijena F trupaca četinara na nivou Federacije $\mathrm{BiH} 177,8 \mathrm{KM} / \mathrm{m}^{3}$, a varira u rasponu od 130 do $351 \mathrm{KM} / \mathrm{m}^{3}$. I kod ostalih sortimanata se javljaju veliki rasponi u cijenama; trupci za rezanje I klase četinara $1: 1,4$, trupci za rezanje II klase 1:1,51, F trupci bukve 1:2,5, F trupci plemenitih lišćara $1: 1,9$, a takođe i cijene manje vrijednih sortimenata (celuloza četinara i lišćara) variraju i imaju raspon od 1:1,5. 


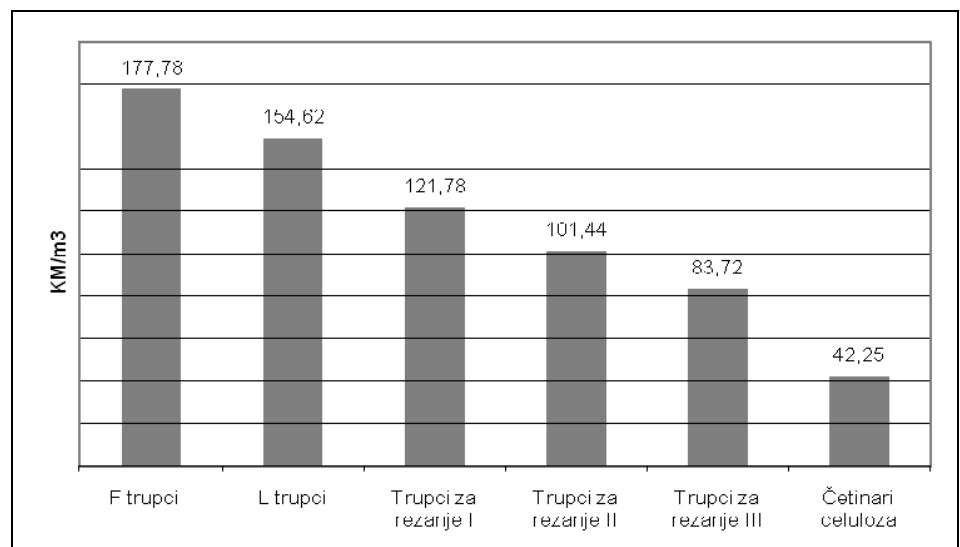

Grafikon 1. Prosječne cijene četinara u Federaciji BiH u 2006.g. Graph 1. Average prices of conifers in Federation of B\&H, 2006.

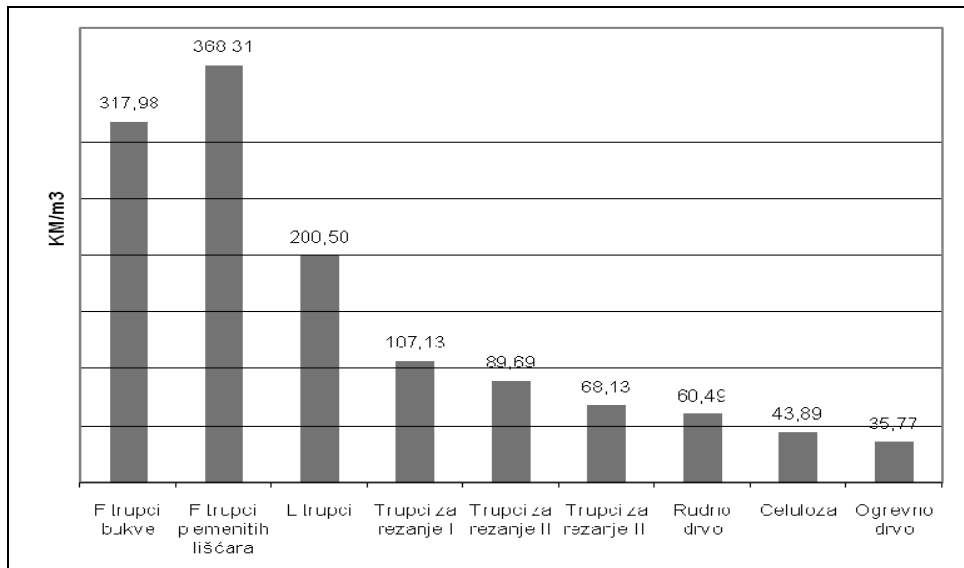

Grafikon 2. Prosječne cijene lišćara u Federaciji BiH u 2006.g.

Graph 2. Average prices of broadleaved in Federation of B\&H, 2006.

\subsubsection{Kvalitetna struktura etata}

Jedan od pokazatelja za ocjenu kvalitetne strukture etata je i ostvareni prihod od etata sveden na jedinicu površine sa koje je realizovan etat (Delić, 2006). Prosječna vrijednost ovog pokazatelja na nivou Federacije BiH iznosi 184,2 KM/ha, a posmatrano po preduzećima varira od 25 do $267 \mathrm{KM} /$ ha (tabela 2). To ukazuje na uticaj različitih prirodnih uslova, a prije svega kvaliteta staništa na kvalitetnu strukturu etata iz koje se realizuje prihod. Kvalitet realizovanog etata direktno utiče na asortiman šumskih drvnih proizvoda i na ostareni prihod. 
Tabela 2. Pokazatelj kvaliteta etata

Table 2. Index of feeling volume quality

\begin{tabular}{|l|c|}
\hline \multicolumn{1}{|c|}{$\begin{array}{c}\text { ŠUMSKOGOSPODARSKO } \\
\text { PREDUZEĆE }\end{array}$} & $\begin{array}{c}\text { Prihod od } \\
\text { etata } \\
\text { KM/ha }\end{array}$ \\
\hline \hline Unsko-sanske šume & 217,70 \\
\hline Šume TK & 253,43 \\
\hline ŠGP ZE-DO kantona & 183,54 \\
\hline Bosansko-podrinjske šume & 59,26 \\
\hline Srednjobosanske šume & 196,62 \\
\hline Hercegovačko-neretvanski kanton & 44,45 \\
\hline Ž ZH d.o.o.Posušje & 24,96 \\
\hline Sarajevo-šume & 267,23 \\
\hline Hercegbosanske šume & 200,08 \\
\hline FEDERACIJA BIH & 184,17 \\
\hline \hline
\end{tabular}

Pored ovog, kao izvedeni pokazatelj kvaliteta etata može poslužiti koeficijent kvaliteta etata. On pokazuje potencijalnu vrijednost prihoda od etata pod pretpostavkom da cjelokupnu količinu etata čine pilanski trupci (MARTINIĆ, 1996).

Prema ovom autoru, koeficijent kvaliteta etata se računa posebno za lišćare i četinare prema obrazcu:

$$
K_{k e}=\frac{U P_{e}}{Q_{n} \cdot C_{t r}}
$$

gdje je:

$K_{k e} \quad \ldots \ldots$. koeficijent kvaliteta etata

$U P_{e} \quad \ldots$. ukupan prihod od etata

$Q_{n} \ldots \ldots$ ukupna neto masa svih sortimenata

$C_{t r} \ldots \ldots$ cijena trupaca za rezanje (prosječna)

Ako je $K_{k e}=1$, znači da je postignuta kvalitetna struktura etata jednaka kvalitetu pilanskih trupaca. Iako se u praksi nikada ne postiže ova pretpostavljena vrijednost, izračunati koeficijent ukazuje na kvalitet realizovanog etata. Što je vrijednost koeficijenta bliža jedinici, radi se o boljem kvalitetu etata i obrnuto.

\subsection{Struktura troškova poslovanja preduzeća}

U cilju utvrđivanja poslovnog rezultata preduzeća izvršena je analiza ostvarenih troškova po pojedinim preduzećima i na nivou šumarstva Federacije BiH. Ukupni troškovi poslovanja svih preduzeća u 2006. godini iznosili su 179,67 miliona KM sa sljedećom strukturom (grafikon 3): 
- $39 \%$ troškovi radne snage

$-4,7 \%$ amortizacija

- $10,2 \%$ materijalni troškovi

- 46,2 \% ostali troškovi i usluge (usluge sječe i izrade)

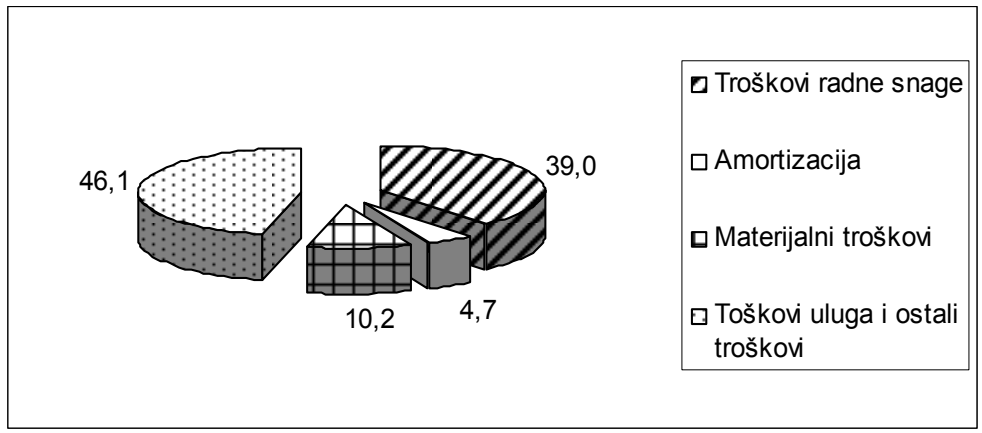

Grafikon 3. Struktura troškova poslovanja na nivou šumarstva Federacije BiH u 2006.g. Graph 3. Cost structure of B\&H Federation forestry, 2006.

Troškovi radne snage variraju po preduzećima i iznose od $27,7 \%$ do $51,5 \%$, troškovi amortizacije od $1 \%$ do $8 \%$. Ovi pokazatelj govore o različitom stepenu tehničke opremljenosti pojedinih preduzeća i različitom stepenu opterećenosti radnom snagom. I materijalni troškovi participiraju u različitom iznosu po pojedinim preduzećima. Troškovi usluga i ostali troškovi u sebi sadrže troškove sječe i izrade drvnih sortimenata, a preduzeća koja su ovu fazu privatizirala, obračunala su ove troškove kao usluge, te je ova stavka u strukturi troškova jako visoka. Struktura troškova po preduzećima je prikazana na grafikon 4 .

$\mathrm{Za}$ analizu su posebno bili interesantni troškovi iskorištavanja šuma i biološke reprodukcije po pojedinim preduzećima (tabela 3 ). U ove troškove su uračunati samo direktni troškovi, bez raspoređenog dijela opštih troškova. Kao što se vidi, direktni troškovi iskorištavanja na nivou Federacije iznose $21,77 \%$ od ukupnih troškova, uz variranje po preduzećima od $15 \%$ do $30 \%$. Osnovni razlozi za pojavu ovakvih razlika se mogu naći u načinu obračuna i obuhvatanja pojedinih troškova, načinu realizacije ove faze (sopstvena ili tuđa režija), ali svakako i zbog različitih uslova privređivanja. Dobiveni iznos troškova iskorištavanja po jedinici realizovane proizvodnje $\left(\mathrm{m}^{3}\right)$ su nerealno niski, te ne mogu biti osnov za komparaciju i donošenje zaključaka o stvarnim troškovima sječe i izrade. Komparacije radi, neka istraživanja ${ }^{5}$ su pokazala da prosječni troškovi sječe, izrade i izvoza šumskih drvnih sortimenata variraju od 26,70 do 42,76 KM $/ \mathrm{m}^{3}$. Očigledna razlika potvrđuje konstataciju da se kalkulacijama nisu obuhvatili svi troškovi.

\footnotetext{
${ }^{5}$ Završni izvještaj projekta Benchmarking u šumarstvu BiH , str. 36.
} 


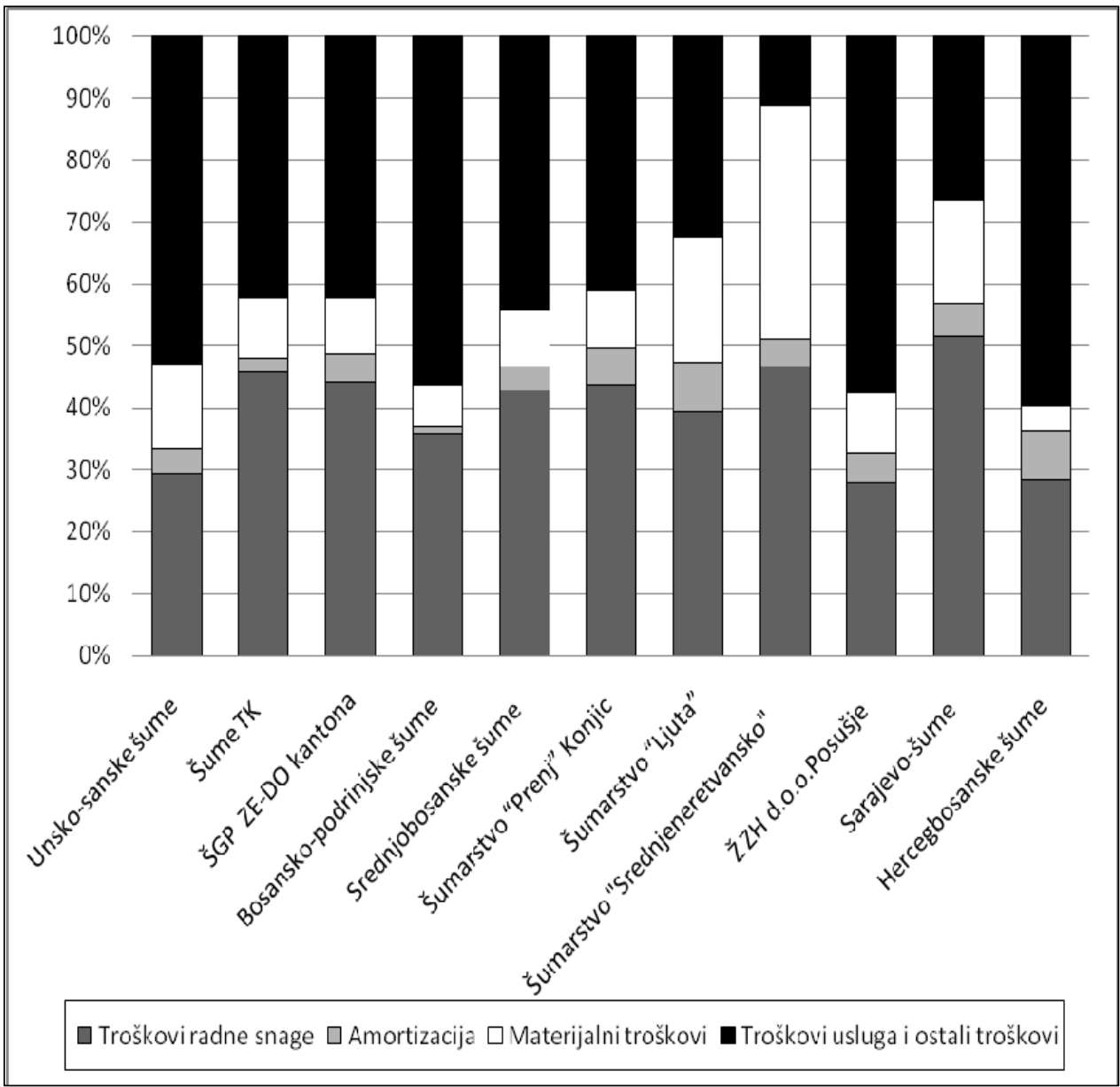

Grafikon 4. Struktura troškova poslovanja preduzeća šumarstva u Federaciji BiH u 2006. g. Graph 4. Costs structure of forestry enterpises in Federaton of B\&H, 2006.

Troškovi biološke reprodukcije (direktni troškovi šumskouzgojnih radova, troškovi izgradnje i rekonstrukcije šumskih kamionskih puteva) čine 11,75\% ukupnih troškova preduzeća šumarstva, što ukazuje na nizak obim radova iz područja biološke reprodukcije, posebno što oko $40 \%$ ovih troškova otpada na troškove izgradnje i rekonstrukcije puteva.

Prosječni troškovi biološke reprodukcije na nivou Federacije BiH iznose $11,6 \%$ od ukupnog prihoda, odnosno $14,5 \%$ prihoda od drveta. To znači da su izdvojena i utrošena sredstva u biološku reprodukciju manja od zakonski propisanog minimuma (6). Samo su neka preduzeća utrošila veći iznos od minimalno zakonski propisanog iznosa, tj. $15 \%$ prihoda od drveta za prostu reprodukciju i $3 \%$ za proširenu (grafikon 5). 
Tabela 3. Direktni troškovi sječe, izrade i izvoza i troškovi biološke reprodukcije Table 3. Direct costs of forest utilization and biological reproduction

\begin{tabular}{|l|r|c|c|r|c|}
\hline \multirow{2}{*}{$\begin{array}{c}\text { ŠUMSKOGOSPODARSKO } \\
\text { PREDUZEĆE }\end{array}$} & \multicolumn{2}{|c|}{ Ukupni troškovi sječe i izrade } & \multicolumn{2}{c|}{$\begin{array}{c}\text { Troškovi biološke } \\
\text { reprodukcije }\end{array}$} \\
\cline { 2 - 6 } & KM & $\begin{array}{c}\text { Učešće u } \\
\text { ukupnim } \\
\text { troškovima } \\
\%\end{array}$ & $\begin{array}{c}\text { Troškovi po } \\
\text { jedinici } \\
\text { proizvodnje } \\
\text { KM/m3 }\end{array}$ & KM & $\begin{array}{c}\text { Učěće u } \\
\text { ukupnim } \\
\text { troškovima \% }\end{array}$ \\
\hline Unsko-sanske šume & 9.967 .575 & 29,39 & 18,54 & 4.263 .063 & 12,57 \\
\hline Šume TK & 2.552 .614 & 15,76 & 10,36 & 2.448 .013 & 15,11 \\
\hline ŚGP ZE-DO kantona & 5.948 .345 & 17,83 & 13,31 & 2.435 .286 & 7,30 \\
\hline Bosansko-podrinjske šume & 231.741 & 17,29 & 6,00 & 266.722 & 19,90 \\
\hline Srednjobosanske šume & 8.188 .983 & 23,44 & 17,84 & 4.794 .187 & 13,72 \\
\hline Hercegovačko-neretvanski kanton & 1.275 .982 & 14,67 & 13,98 & 1.046 .805 & 12,03 \\
\hline Ž ZH d.o.o.Posušje & 144.000 & 25,84 & 16,61 & 219.500 & 39,38 \\
\hline Sarajevo-šume & 3.690 .881 & 19,67 & 21,07 & 4.001 .218 & 19,67 \\
\hline Hercegbosanske šume & 7.116 .083 & 23,47 & 12,06 & 1.441 .331 & 4,75 \\
\hline FEDERACIJA BIH & 39.116 .204 & 21,77 & 15,08 & 21.118 .377 & 11,75 \\
\hline
\end{tabular}

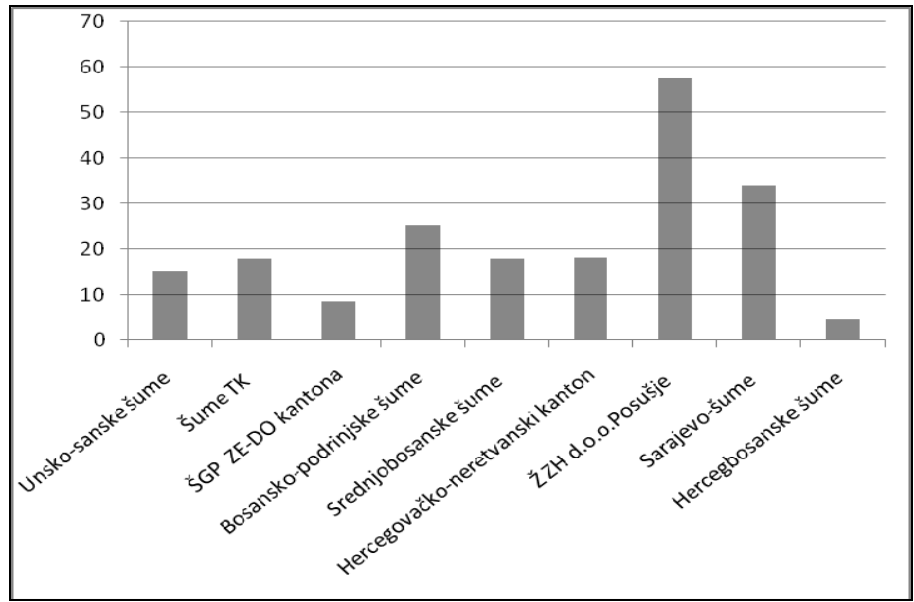

Grafikon 5. Učešće troškova biološke reprodukcije u ukupnom prihodu od drvnih sortimenata u pojedinim preduzećima (\%)

Graph 5. Share costs of biological reproduction in the revenue from forest wood productsin diferent enterprises (\%)

\subsection{Poslovni rezultat}

Kao neto rezultat svake proizvodnje na nivou preduzeća javlja se nova vrijednost koja se izražava kao dobit. Poslovni rezultat predstavlja razliku između ukupno ostvarenog prihoda $i$ utrošenih sredstava u proizvodnji tj. troškova proizvodnje (ŠunJIĆ-BEUS, 1999). U šumarstvu Federacije BIH je u 2006. godini ostvarena bruto dobit od 2,765 miliona KM. Preduzeća su ostvarila različite iznose dobiti, ili su poslovala negativno iskazujući gubitak (grafikon 6). 


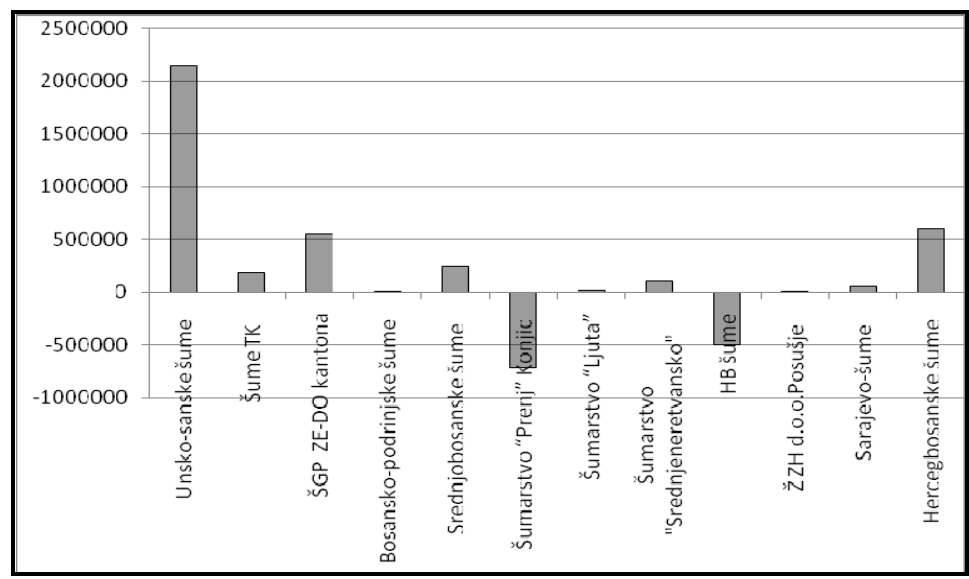

Grafikon 6. Rezultati poslovanja pojedinih preduzeća šumarstva u Federaciji BiH u 2006.g. (dobit/gubitak u KM)

Graph 6. Operating result of forest enterprises in Federation of B\&H, 2006.

Realni pokazatelji uspješnosti poslovanja (pored osnovnih ekonomskih principa; produktivnosti, ekonomičnost i i rentabilnosti) su npr. ostvarena dobit po zaposlenom ili ostvarena dobit po jedinici proizvodnje $\left(\mathrm{m}^{3}\right)$. Prosječno ostvarena dobit po zaposlenom u šumarstvu Federacije BiH iznosi 611,16 KM uz variranje od $60 \mathrm{KM}$ do 3,2 hiljade KM. Preduzeća koja su negativno poslovala ostvarila su gubitak od 4,6 hiljada, odnosno 7 hiljada KM po zaposlenom.

Prosječna dobit po $\mathrm{m}^{3}$ neto proizvedenog drveta iznosi $1,25 \mathrm{KM}$ na nivou Federacije. U tabeli 4. je dat prikaz ovih pokazatelja po preduzećima.

Tabela 4. Pokazatelji ostvarene dobiti

Table 4. Indikators of realised profit

\begin{tabular}{|c|c|c|c|c|c|}
\hline $\begin{array}{l}\text { ŠUMSKOGOSPODARSKO } \\
\text { PREDUZEĆE }\end{array}$ & $\begin{array}{c}\text { Rezultat } \\
\text { poslovanja } \\
\text { Dobit/gubitak } \\
\text { KM }\end{array}$ & $\begin{array}{c}\text { Broj } \\
\text { zaposlenih }\end{array}$ & $\begin{array}{c}\text { Dobit/gubitak } \\
\text { po } \\
\text { zaposlenom } \\
\text { KM/radniku }\end{array}$ & $\begin{array}{c}\text { Ostvarena } \\
\text { neto } \\
\text { proizvodnja } \\
\mathrm{m}^{3}\end{array}$ & $\begin{array}{c}\text { Dobit/gubitak } \\
\text { po m3 } \\
\text { proizvodnje } \\
\mathrm{KM} / \mathrm{m}^{3}\end{array}$ \\
\hline Unsko-sanske šume & 2.148 .922 & 662 & 3246,11 & 450.189 & 4 \\
\hline Šume TK & 177.396 & 533 & 332,83 & 204.712 & 0,87 \\
\hline ŠGP ZE-DO kantona & 553.040 & 1065 & 519,29 & 375.928 & 1,47 \\
\hline Bosansko-podrinjske šume & 2.457 & 40 & 61,43 & 32.585 & 0,08 \\
\hline Srednjobosanske šume & 247.590 & 1052 & 235,35 & 423.629 & 0,58 \\
\hline Šumarstvo "Prenj” Konjic & -717.784 & 156 & $-4601,18$ & 51.702 & $-13,88$ \\
\hline Šumarstvo "Ljuta" & 79.636 & 31 & 2568,90 & 7.637 & 10,43 \\
\hline $\begin{array}{l}\text { Sumarstvo } \\
\text { "Srednjeneretvansko" }\end{array}$ & 106.982 & 43 & 2487,95 & 10.783 & 9,92 \\
\hline HB šume & -499.857 & 72 & $-6942,46$ & 8.581 & $-58,25$ \\
\hline Ž ZH d.o.o.Posušje & 7.648 & 12 & 637,33 & 6.790 & 1,13 \\
\hline Sarajevo-šume & 58.891 & 379 & 155,39 & 145.981 & 0,40 \\
\hline Hercegbosanske šume & 600.557 & 480 & 1251,16 & 498.917 & 1,20 \\
\hline FEDERACIJA BIH & 2.765 .478 & 4525 & 611,16 & 2.217 .334 & 1,25 \\
\hline
\end{tabular}




\section{ZAKLJUČCI - Conclusions}

Šumarstvo Federacije svoj prihod uglavnom bazira na šumskim drvnim sortimentima, a mogućnost povećanja prihoda po osnovu iskorištavanja specijalnih šumskih proizvoda ili po osnovu razvoja drugih djelatnosti, gotovo se ne koristi i pored izuzetnih potencijala naših šuma. Zbog toga, cijene šumskih drvnih sortimenata i kvalitetna struktura etata imaju odlučujuću ulogu u formiranju ukupnog prihoda šumarstva.

Realizacija šumskih drvnih proizvoda u analiziranoj godini se uglavnom izvršila u skladu sa cijenama koje su definisane minimalnim cjenovnikom od strane preduzeća. Samo u nekim preduzećima je bila zastupljena prodaja putem licitacije, ali se radi o neznatnoj količini drvnih sortimenata. Cijene po cjenovniku za iste sortimente su različite po preduzećima i može se reći da su one iskustvene, a ne tržišne. To se na direktan način odražava na poslovni uspjeh.

S obzirom na to, može se zaključiti da se privređivanje u šumarstvu ne zasniva na integralnom i multifunkcionalnom korišćenju šumskih resursa, jer se:

- ne ostvaruju realno mogući prihodi po osnovu iskorišćavanja sekundarnih šumskih proizvoda, sekundarnih dijelova biomase (četine, sitna granjevina i dr.),

- privređivanje po osnovu lovstva nalazi na niskom nivou,

- ne ostvaruju prihodi po osnovu turističkih, rekreativnih i drugih socioloških i ekološko-zaštitnih funkcija šuma.

Preduzeća šumarstva u Federaciji $\mathrm{BiH}$ imaju različite uslove privređivanja (prirodne, materijalno-tehničke i ljudske resurse) iz kojih proizilaze i različite mogućnosti sticanja prihoda.

Obračun troškova se ne vrši po jedinstvenoj metodici, što stvara problem pri komparaciji. Struktura troškova poslovanja jako varira između preduzeća, što se direktno odražava na rentabilnost.

$\mathrm{U}$ analiziranoj godini je prosječna ostvarena dobit po jedinici proizvodnje $\left(\mathrm{m}^{3}\right)$ na nivou Federacije iznosila 1,25 KM, uz dijapazon variranja od 0,08 do $9,92 \mathrm{KM} / \mathrm{m}^{3} \mathrm{u}$ pojedinim preduzećima, dok je gubitak u preduzećima koja su negativno poslovala iznosio $13,88 \mathrm{KM}$, odnosno $58,25 \mathrm{KM}$ po $\mathrm{m}^{3}$ proizvedenog drveta. Zato je i akumulativna $\mathrm{i}$ reproduktivna sposobnost preduzeća na različitom nivou. Iz ovog proizlazi da se u pojedinim situacijama država kao vlasnik resursa, ne bi trebala osloniti na materijalne mogućnosti preduzeća kada su u pitanju investiranja u biološku reprodukciju. U protivnom, moglo bi doći do narušavanja principa kontinuiteta gospodarenja šumskim resursima.

\section{Zahvala - Acknowledgement}

Ovaj rad je dio rezultata istraživanja u okviru projekta „Istraživanje cijene gospodarenja šumama i šumskim zemljištem na području Federacije $\mathrm{BiH}^{\text {“, }}$ koji je finansiran od strane Federalnog ministarstva poljoprivrede, vodoprivrede i šumarstva, na čemu se ovom prilikom zahvaljujemo. 


\section{LITERATURA - Literature}

DELIĆ, S. (2006): Istraživanje modela finansiranja biološke reprodukcije u šumarstvu Bosne i Hercegovine, doktorska disertacija, Šumarski fakultet, Sarajevo

Delić, S: (2008): Biological Reproduction in forestry in Bosnia and Herzegovina Practical issues of the forest law, (in press)

MARTINIĆ, I. (1996): Ekonomski i organizacijski kriteriji za oblikovanje šumskih radova, Glasnik za šumske pokuse, Vol. 33. str. 215-299, Zagreb,

ŠAKOVIĆ, Š. (1998): Neke ekonomske karakteristike proizvodnje u šumarstvu kao osnovice za formulaciju šumarske politike

ŠunJić - Beus, M., Berberović, Š., STAVRIĆ, B. (1999): Ekonomika preduzeća, Ekonomski fakultet, Sarajevo

Plan rada i poslovanja za 2006. godinu preduzeća šumarstva u Federaciji BiH

Izvještaji o poslovanju preduzeća za period januar-decembar 2006. godine,

Zakon o šumama (2002): Službene novine Federacije BiH

Završni izvještaj projekta Benchmarking u šumarstvu BiH

\section{SUMMARY - Sažetak}

The results of this analysis show that Forest Management Companies (FMCs) in the Federation of B-H, obtain $80 \%$ of their revenues from wood assortments production. Only $20 \%$ of their revenues come from non-wood forest products and other sources. This clearly points out that forestry in the Federation of B-H is not based on the principles of multifunctional management of forest resources.

Having in mind the differences in production conditions among Forest Management Companies (FMCs), the structure of their costs varies also. For instance, the share of labour costs in different FMCs varies between 27,7\% and 51,5\%. As concerns the costs of utilization as well as the costs of biological reproduction, there are also significant differences. These differences are not caused merely by different production conditions but also by the way how the specific types of costs are calculated. The financial assets allocated for biological reproduction amount 14,5\% of realized revenue what is less then the legally prescribed minimal rate.

The different cost and revenue structure has direct implications on Forest Management Companies' business results but also to their accumulative and reproductive capabilities. Current planning of biological investments is mainly based on Forest Management Companies' financial possibilities. As they are not planed according to the real need, such a forest investment policy is not sustainable. The implications on forest resources might be very serious and this is what the Federation of $\mathrm{B}-\mathrm{H}$ as the owner should take into account. 


\section{UPUTE AUTORIMA}

Časopis «Radovi» Šumarskog fakulteta Univerziteta u Sarajevu objavljuje znanstvene radove, prikaze znanstvenih djela i stručne radove iz područja šumarstva, hortikulture, ekologije, zaštite prirode, lovstva, te iz drugih područja značajnih za razvoj šumarstva i hortikulture.

Radovi koji se dostavljaju radi objavljivanja moraju biti napisani jednim od službenih jezika naroda $\mathrm{BiH}$ ili na engleskom jeziku, do 15 stranica teksta s proredom (uključivo i priloge), na papiru formata A4. U iznimnim slučajevima Uređivački odbor časopisa može prihvatiti radove nešto većeg opsega, ako sadržaj i kvaliteta to opravdavaju.

Znanstveni radovi, a u pravilu i stručni radovi, treba da imaju uobičajenu strukturu, i to:

$>$ naslov rada se piše velikim slovima, dvojezično, centralno poravnat (naslov na kojem je jeziku pisan članak se piše velikim, boldiranim slovima).

$>$ ispod naslova se navodi ime(na) i prezime(na) autora, boldiranim slovima a naziv(i) institucije(a) u fusnotama označene zvjezdicama koje su pridodate uz prezime(na) autora.

$>$ prije uvoda treba napisati kratak izvod - abstract (do 200 riječi sa izdvojenim ključnim riječima), dvojezično. Pojmove «izvod» odnosno «abstract», te «ključne riječi» odnosno «kye words» pisati boldiranim slovima.

$>$ zatim slijede: uvod, metoda(e) rada, rezultat(i) istraživanja, diskusija, zaključak, zahvale, literatura, sažetak . Ovi se podnaslovi pišu boldiranim slovima i dvojezično, sažetak samo na jednom jeziku.

$>$ Literatura - popis djela koja se citiraju u radu - navodi se abecednim redom autora i hronološki: prezime i inicijal imena prvog autora, a za ostale autore ispred prezimena piše se inicijal imena, godina, naziv djela, časopis u kojem je djelo objavljeno (mogu se koristiti i standardne skraćenice), volumen, broj, stranice, mjesto. Nije dozvoljeno unos i citiranje radova koji nisu objavljeni. U tekstu se citirani izvori navode unošenjem u zagradi - (prezime autora, godina).

$>$ Sažetak sadrži više detalja o metodu(ima) i rezultatima istraživanja. Ukoliko je rad pisan na engleskom jeziku summary se zamjenjuje sažetkom na jednom od službenih jezika naroda $\mathrm{BiH}$.

$>$ Latinska imena navode se kurzivom (italic).

$>$ Tabele, grafikoni, crteži, slike moraju imati svoj naziv, a ako ih je više i broj. Broj i naziv tabele se pišu u istom redu iznad tabele, dok se broj i naziv grafikona, crteža, slika pišu ispod tih priloga. Nazive ovih priloga i njihove opise treba dati dvojezično. Tabele, ukoliko je nužno, uokviriti linijama debljine $1 \mathrm{pt}$. 
Fusnote u tabelama označavaju se malim slovima i navode se odmah iza tabela, a fusnote $\mathrm{u}$ tekstu označavaju se redosljedom arapskim brojevima, na dnu stranice gdje se spominju.

Elektronsku verziju rada treba pripremiti u Word programu na formatu stranica $170 \times 240 \mathrm{~m} / \mathrm{m}$, sa marginama: gornja i donja $2,4 \mathrm{~cm}$, vanjska $2,0 \mathrm{~cm}$, a unutarnja 1.5 $\mathrm{cm}$, te formatizirati parne i neparne stranice. Koristiti Times New Roman, veličina 11 $p t$. Tekst treba da je obostrano poravnat. Stranice nije potrebno numerirati.

Predaje se jedan odštampan primjerak rada i rad spremljen na disketi ili CD ili slanjem putem elektronske pošte.

Radovi se recenziraju. Primljeni radovi sa prilozima se ne vraćaju.

Uredništvo «RADOVA»

Šumarski fakultet

71000 Sarajevo,

Zagrebačka 20

Telefon: 033/614 003

Telefax: 033/611349

E-mail:mirzad@bih.net.ba 
